\title{
Preliminary sensory evaluation of grape pomace flour sweet cookies
}

\author{
Avaliação sensorial preliminar de bolachas doces de farinha de bagaço de uva
}

\author{
M. Lídia Palma ${ }^{1 *}$, Cíntia Ferreira-Pêgo ${ }^{1}$, Marisa Nicolai ${ }^{1}$, Paula Pereira ${ }^{1,2}$ \\ ${ }^{1}$ CBIOS - Universidade Lusófona's Research Center for Biosciences and Health Technologies, Av. Campo Grande 376, 1749- \\ 024 Lisbon, Portugal \\ ${ }^{2}$ CERENA - Instituto Superior Técnico (IST) Center for Natural Resources and Environment, Universidade de Lisboa, Av. \\ Rovisco Pais, 1049-001 Lisboa, Portugal \\ *corresponding author: p1814@ulusofona.pt
}

\begin{abstract}
The sustainable use of resources and industrial waste is an important objective for environmental preservation and in the search for potential new foods and ingredients. Considering the size and importance of the wine industry, the use of winemaking waste in a sustainable manner is important for producers. Given the nutritional characteristics of this by-product, its use as an ingredient may be an interesting source of income, especially in Portugal, where around 183 thousand tons of this waste are generated annually. In addition to studies regarding the nutritional characteristics and active constituents, it is necessary to evaluate the acceptability of potential buyers to different food matrices resulting from the incorporation of grape pomace flour. This study was designed to evaluate the acceptability of sweet cookies with the incorporation of different percentages of grape pomace flour resulting from the vinification of Arinto and Touriga Nacional grape varieties. The sensory assessment of 149 individuals was evaluated using a questionnaire developed for this purpose. The results obtained are not conclusive, but there is a tendency for the preference for cookies with the incorporation of grape pomace flour at $15 \%$ versus incorporation of $20 \%$, independent of the caste used.
\end{abstract}

Keywords: Grape pomace; sweet cookies; sensory evaluation; Touriga Nacional; Arinto

\section{Resumo}

A utilização sustentável de recursos e resíduos industriais, constituem um importante objetivo para a preservação ambiental e para a procura potencial de novos alimentos e ingredientes. Considerando a dimensão e importância da indústria vitivinícola, o aproveitamento dos resíduos da vinificação de uma forma sustentável constitui um objetivo para produtores. Atendendo às caraterísticas nutricionais deste subproduto a sua utilização como ingrediente pode constituir uma importante fonte de rendimento, em especial em Portugal onde são gerados anualmente cerca de 183 mil toneladas deste resíduo. Para além dos estudos de caraterização nutricional torna-se necessário avaliar a aceitabilidade de potenciais compradores face a diferentes matrizes alimentares resultantes da incorporação de farinha de bagaço. Este estudo avaliou a aceitabilidade de bolachas doces com incorporação de diferentes percentagens de farinha de bagaço de uva, resultante da vinificação das castas de Arinto e Touriga Nacional. Foram avaliadas as respostas de 149 indivíduos face a um questionário de avaliação sensorial desenvolvido para o efeito. Os resultados obtidos não são conclusivos, mas existe uma tendência para a preferência de bolachas com incorporação de $15 \%$ de farinha de bagaço de uva face à incorporação de $20 \%$ independentemente da casta usada. .

Palavras-chave: Bagaço de uva; bolachas doces; avaliação sensorial; Touriga Nacional; Arinto 


\section{Introduction}

The sustainable use of resources and the use of waste are currently important aspects of the political and social agenda of countries at a global level. In this sense, the 2030 agenda of the UN has defined 17 sustainable objectives, which aim to be a common vision of development for humanity, including sustainable production and development (1). The use of waste from the wine industry has been the target of several studies in recent years (2), since its use as fertilizer (3), as a source of antioxidants and polyphenols (4-6) or use in cosmetics (7) and the pharmaceutical industry (8), or as an additive in food (9). The most sustainable way of using pomace seems to be in the form of pomace flour for food purposes. In this way it can constitute not only an important product with food value $(10,11)$ but also an important source of income for the main producing countries. Portugal is included among these countries, with a total planted area of $6.3 \%$ of the total national agricultural area (12) with annual wine production in 2019/202 of about 6.5 million hl (IVV) which generated about 183,000 tons of grape pomace (13). According to Regulation (EC) $1493 / 1999$, pomace is the residue obtained after the pressing of fresh grapes, fermented or not, during the wine production process. Stalks, skins, and pips are integral parts of this residue. We have been studying (14) pomace flour, which results from the drying and milling of pomace. Studies regarding the importance and nutritional characterization of this product have indicated a constitution rich in polyphenols and antioxidants (14), low protein content, and high soluble and insoluble fiber content (15-18).

To introduce this flour as an ingredient in the food industry, it is necessary to complement the characterization studies of this product with consumer sensory evaluation studies using different matrices and different percentages of incorporation. In this sense, after the study of the sensory analysis of the incorporation of flour in a savory cracker (19), where a preference for cookies with higher percentages of incorporation was shown, the main objective of the present study was to preliminarily evaluate the acceptability of a sweet cookie with higher percentages of incorporation of pomace flour from one of two Portuguese grape varietals among a panel of untrained consumers.

\section{Introdução}

A utilização sustentável dos recursos e o aproveitamento de resíduos são, atualmente, importantes aspetos da agenda política e social dos países a nível global. Neste sentido a agenda 2030 da ONU definiu 17 objetivos sustentáveis, que pretendem ser uma visão comum de desenvolvimento para a Humanidade, entre os quais se incluí a produção e desenvolvimento sustentável (1). O aproveitamento de resíduos da indústria do vinho tem sido alvo de vários estudos nos últimos anos (2), desde a sua utilização como fertilizante (3), como fonte de antioxidantes e polifenóis (4-6) para a utilização tanto na cosmética (7) como na industria farmacêutica (8) ou como ingrediente na alimentação (9). A forma mais sustentável de utilização do bagaço parece ser na forma de farinha de bagaço para fins alimentares, já que desta forma pode constituir não só um importante produto com valor alimentar $(10,11)$, como uma importante fonte de rendimento para os principais países produtores, nos quais se insere Portugal em que o total de área plantada é de $6,3 \%$ do total de área agrícola nacional (12) com uma produção anual de vinho em 2019/2020 de cerca de 6,5 milhões de hl (IVV) os quais geraram cerca de 183 mil toneladas de bagaço de uva (13). O resíduo, na forma de farinha de bagaço, que temos vindo a estudar (14), resulta da secagem e moagem do subproduto da vinificação caraterizado como bagaço (13), que de acordo com o regulamento (CE) 1493/1999, estabelece este produto como o resíduo obtido após a prensagem das uvas frescas, fermentado ou não, durante o processo de produção de vinho, do qual fazem parte integrante os engaços, os pedúnculos, as películas e as grainhas. A importância e caraterização nutricional deste produto tem vindo a ser estudada, a qual indica uma constituição rica em polifenóis e antioxidantes (14), baixo teor em proteína e elevado conteúdo em fibra tanto solúvel como insolúvel (15-18).

Com o objetivo de introduzir esta farinha como um ingrediente na indústria alimentar torna-se necessário complementar os estudos de caraterização deste produto com estudos de avaliação sensorial dos consumidores em diferentes matrizes e com diferentes percentagens de incorporação. Neste sentido após o estudo da análise sensorial da incorporação da farinha numa bolacha salgada (19) o principal objetivo do presente estudo foi avaliar, preliminarmente, a aceitabilidade, de consumidores não treinados, para uma bolacha doce com percentagens mais elevada de incorporação de farinha de bagaço de uva, resultante de duas castas portuguesas, já que estudos anteriores demostraram uma preferência por bolachas com percentagens mais elevadas de incorporação (19). 


\section{Materials and Methods}

\section{Biological samples}

The Carmin Cooperative winery in Reguengos de Monsaraz provided two types of grape pomace samples, one of white grape variety (Arinto) and another of red grape variety (Touriga Nacional). After receiving the samples, they were dried in an oven (J.P. Selecta, Barcelona, Spain), for 24 hours at $60{ }^{\circ} \mathrm{C}$, ground in a household slide crusher (Moulinex, Alencon, France), and finally stored in propylene bags properly sealed until their use.

\section{Cookie preparation}

Five sweet cookie recipes were prepared based on a recipe with wheat flour, which was replaced in percentages of $15 \%$ and $20 \%$ by grape pomace flour of the grape varieties (Touriga Nacional and Arinto). The ingredients used in the preparation of the sweet cookies were T55 extra-fine wheat flour (National), refined white sugar (Sidul), butter with salt (Agros), semiskimmed milk (Agros), and grape pomace flour. The quantities of ingredients used are described in Table 1.

In the preparation of the dough, the sugar and butter were first added until a homogeneous and whitish mixture was obtained. Then the wheat flour and/or grape pomace flour and gradually the milk were mixed in to obtain a consistent dough. Finally, the dough was kneaded and allowed to rest for 10 minutes, then rolled thin and cut into small rectangles $(3 \times 2.5 \mathrm{~cm})$. The cookies were placed in an industrial oven (Eka KF912 - Tecnoeka Sri, Padova, Italy) for 10 minutes at 180 ${ }^{\circ} \mathrm{C}$, then remaining in the oven until it was completely cooled. The various stages of preparation of the cookies are shown in Figure 1.

\section{Material e Métodos}

\section{Amostras biológicas}

A adega Cooperativa Carmin em Reguengos de Monsaraz forneceu dois tipos de amostras de bagaço de uva, uma de casta branca (Arinto) e outra de casta tinta (Touriga Nacional). Após a receção das amostras, estas foram secas na estufa (J.P. Selecta, Barcelona, Espanha), durante 24 horas a $60^{\circ} \mathrm{C}$, moídas num triturador de lâminas doméstico (Moulinex, Alencon, França) e por fim armazenadas em sacos de propileno devidamente selados até sua utilização.

\section{Preparação das bolachas}

Procedeu-se à preparação de cinco receitas de bolachas doce, tendo como base uma receita com farinha de trigo, a qual foi substituída nas percentagens de $15 \%$ e $20 \%$ por farinha de bagaço de uva das castas (Touriga Nacional e Arinto). Os ingredientes utilizados na confeção das bolachas doces foram farinha de trigo T55 extrafina (Nacional), açúcar branco refinado (Sidul), manteiga com sal (Agros), leite meio gordo (Agros) e farinha de bagaço de uva. As quantidades de ingredientes usados estão descritas na Tabela 1.

$\mathrm{Na}$ confeção da massa juntou-se primeiro o açúcar com a manteiga até se obter uma mistura homogénea e esbranquiçada. De seguida, misturou-se a farinha de trigo e/ou farinha de bagaço de uva e, aos poucos, o leite de modo a obter-se uma massa consistente. Por fim, amassou-se e repousou por 10 minutos, de seguida estendeu-se e recortou-se em pequenos retângulos $(3 \times 2,5 \mathrm{~cm})$. As bolachas foram colocadas no forno industrial (Eka KF912 - Tecnoeka Sri, Padova, Italia) durante 10 minutos a $180{ }^{\circ} \mathrm{C}$ até arrefecimento total do forno. Na Figura 1 podem observar-se as várias etapas de preparação das bolachas.

Table 1 - Ingredients in the formulation of the sweet cookies

Tabela 1 - Ingredientes da formulação das bolachas doces

\begin{tabular}{cccc}
\hline Ingredients / Ingredientes & $\begin{array}{c}\text { Control / } \\
\text { Controlo }\end{array}$ & $\begin{array}{c}\text { 15\% Incorporation / } \\
\text { Incorporação }\end{array}$ & $\begin{array}{c}\text { 20\% Incorporation / } \\
\text { Incorporação }\end{array}$ \\
\hline $\begin{array}{c}\text { Wheat flour / } \\
\text { Farinha de trigo, } \mathbf{g}\end{array}$ & $250 \pm 0.01$ & $212.5 \pm 0.01$ & $200 \pm 0.01$ \\
\hline $\begin{array}{c}\text { White sugar / } \\
\text { Açúcar branco, } \mathbf{g}\end{array}$ & $125 \pm 0.01$ & $125 \pm 0.01$ & $125 \pm 0.01$ \\
\hline Butter / Manteiga, g & $60 \pm 0.01$ & $60 \pm 0.01$ & $60 \pm 0.01$ \\
\hline Milk / Leite, mL & $50 \pm 0.01$ & $50 \pm 0.01$ & $50 \pm 0.01$ \\
\hline $\begin{array}{c}\text { Grape pomace flour / } \\
\text { Farinha de bagaço de uva, } \mathbf{g}\end{array}$ & - & $37.5 \pm 0.01$ & $50 \pm 0.01$ \\
\hline
\end{tabular}




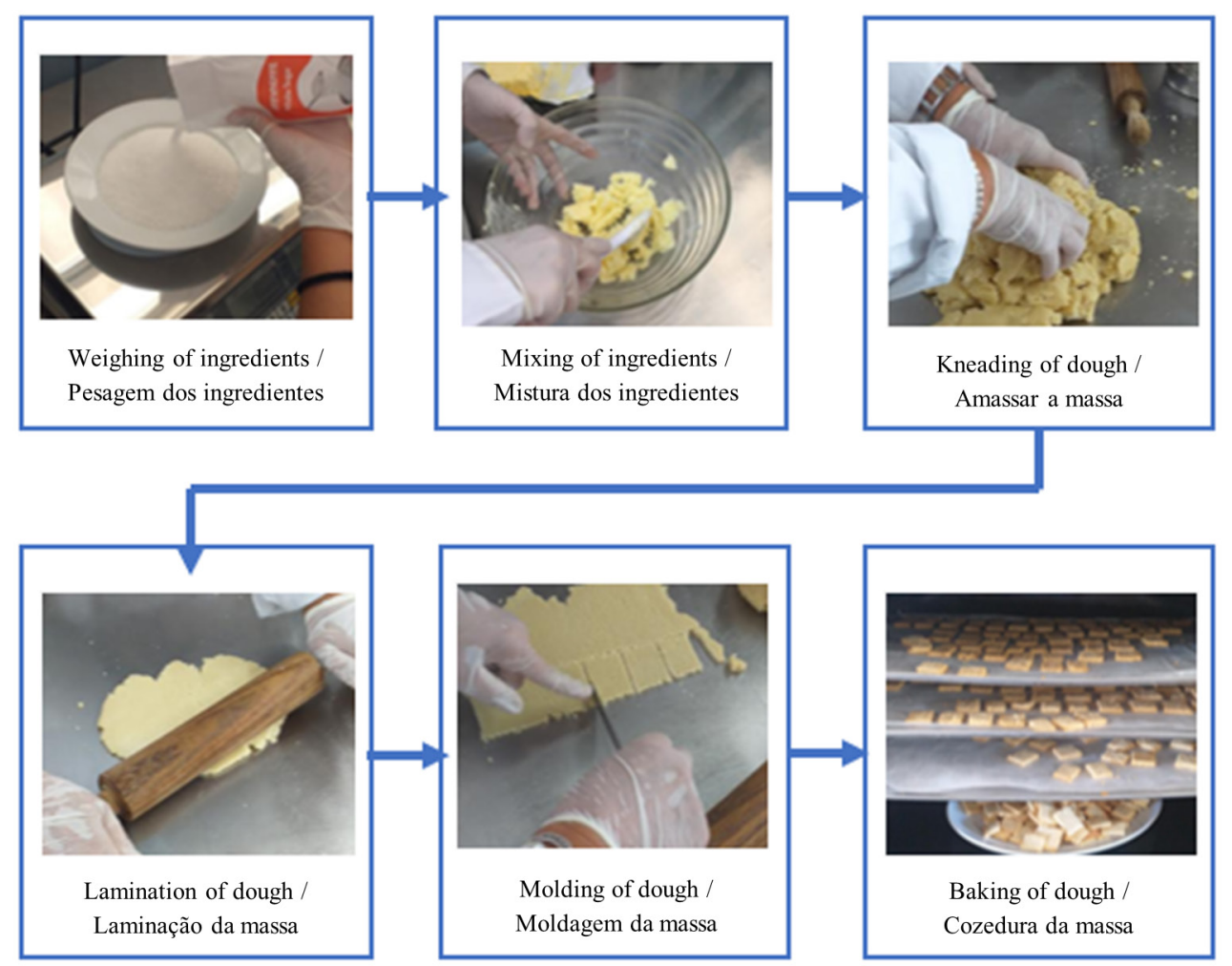

Figure 1 - Preparation of sweet crackers with incorporation of grape pomace flour

Figura 1 - Preparação de bolachas doces com incorporação de farinha de bagaço de uva

\section{Sensory evaluation}

This study aimed at the preliminary analysis of sensory evaluation in a group of 149 untrained individuals of both sexes, aged between 18 and 88 years. Although the use of trained tasters panels is more commonly used in this type of evaluation, the use of untrained panels can be justified for the options of free choice, or nonvalidated questionnaires (20), as is the present case.

For the sensory test, taking into account the current pandemic context and the recommendations and norms of the General Directorate of Health (DGS), a questionnaire was created through the Google Forms platform, which the tasters accessed through a QR code on their smartphone or tablet and thus recorded their opinion at the time of the test. Participants were randomly recruited at the university campus on the tasting tests day.

Two tests were carried out on different days. The sensory test with integration of the Arinto caste grape pomace included 74 participants of both sexes aged between 16 and 88 (PD:17.27) years, and the test for the Touriga Nacional caste grape pomace included 66 participants of both sexes aged between 18 and 88 (PD: $15.88)$ years. The frequency scale used was developed

\section{Avaliação sensorial}

O presente estudo teve como objetivo a análise preliminar de avaliação sensorial num grupo de 149 indivíduos não treinados, de ambos os sexos, de idades compreendidas entre os 18 e os 88 anos. Embora a utilização de painéis de provadores treinados seja mais utilizada neste tipo de avaliação o uso de painéis não treinados pode ser justificada para as opções de livre escolha ou questionários não validados (20), como é o caso do presente estudo.

Para a realização da prova sensorial, tendo em conta o atual contexto de pandemia e as recomendação e normas da Direção Geral da Saúde (DGS) foi criado um questionário, através da plataforma Google Forms, ao qual os provadores acediam através de um código QR no seu smartphone ou tablet e assim registavam a sua opinião no momento da prova. Os participantes foram aleatoriamente recrutados no campus universitário no dia da avaliação sensorial.

Foram realizadas duas provas, em dias distintos, tendo participado na prova sensorial com integração nas bolachas da casta Arinto 74 indivíduos de ambos os sexos de idades compreendidas entre os 16 e 88 (DP:17.27) anos, e na casta Touriga Nacional 66 
Table 2 - Hedonic and willingness to purchase scales

Tabela 2 - Escala hedónica e Intenção de compra

\begin{tabular}{c|ll}
\hline \multicolumn{2}{l}{ Hedonic / Hedónica } & Purchase / Compra \\
\hline 5 & Very pleasant / Muito agradável & Certainly buy / Compraria de certeza \\
4 & Pleasant / Agradável & Would probably buy / Provavelmente compraria \\
3 & Indifferent / Indiferente & Do not know if I would buy / Não sei se compraria \\
2 & Unpleasant / Desagradável & Probably would not buy / Provavelmente não compraria \\
1 & Very unpleasant/ Muito desagradável & Certainly would not buy / Não compraria de certeza \\
\hline
\end{tabular}

by Palma and collaborators (19) in which the tasters gave their opinion regarding color, taste, texture, aroma, and overall final impression. The intention to purchase was also parameterized according to a 5 point scale according to that previously used by the same authors (19) and is described in Table 2. A comparative assessment of the samples was also made using a 3 point scale described in Table 4 and previously used by the authors (19).

\section{Statistical analysis}

Data were presented either as means and standard deviation (SD) for continuous variables or numbers and percentages for dichotomous variables. We compared the distribution of the selected characteristics between groups using Pearson $\chi^{2}$ tests for categorical variables or Student's t-tests or analysis of variance (ANOVA), as appropriate, for continuous variables. All statistical tests were two-tailed and the significance level was set at $\mathrm{P}<0.05$. All analyses were performed using the SPSS software version 26.0 (SPSS Inc, Chicago, IL, USA).

\section{Results and Discussion}

A total of 149 individuals (57 men and 92 women) with an average age of $40.45(\mathrm{SD}=16.45)$ participated in this work. The mean age according to sex and castes are summarized in Table 3. Individuals who tasted sweet cookies with the incorporation of Arinto bagasse flour had a mean age of 39.21 years, and those who tasted cookies with the incorporation of Touriga Nacional bagasse flour had a mean age of 41.96 years. No statistically significant differences were observed between the age and gender of the tasters who evaluated the two varieties. Figure 2 shows the results obtained from the sensory evaluation according to the different varieties and incorporations studied, in which it is possible to observe statistically significant differences regarding color, flavor, taste, and texture. Regarding indivíduos de ambos os sexos de idades compreendidas entre os 18 e os 88 (DP: 15.88) anos.

A escala de frequência usada foi desenvolvida por Palma e colaboradores (19) na qual os provadores deram opinião relativamente à cor, sabor, textura, aroma e impressão global final. A intenção de compra foi igualmente parametrizada segundo uma escala com 5 pontos de acordo com a anteriormente utilizada pelos mesmos autores (19) e descrita na Tabela 2, foi ainda feita uma apreciação comparativa das amostras avaliada por uma escala de 3 pontos descrita na tabela 4 e já anteriormente usada pelos autores (19)

\section{Análise estatística}

Os dados foram apresentados como médias e desvio padrão (DP) para variáveis contínuas ou números e percentagens para variáveis dicotómicas. Comparámos a distribuição das características selecionadas entre os grupos usando testes de Pearson $\chi^{2}$ para variáveis categóricas ou testes t de Student ou análise de variância (ANOVA), conforme apropriado, para variáveis contínuas. Todos os testes estatísticos foram bicaudais e o nível de significância foi estabelecido em $\mathrm{P}<0,05$. Todas as análises foram realizadas utilizando o software SPSS versão 26.0 (SPSS Inc, Chicago, IL, EUA).

\section{Resultados e Discussão}

Um total de 149 indivíduos (57 homens e 92 mulheres) com uma idade média de 40,45 ( $\mathrm{DP}=16.45)$ anos participaram no presente trabalho. A idade média de acordo com o sexo e com as castas estão resumidas na Tabela 3. Os indivíduos que provaram bolachas doces com incorporação de farinha de bagaço de Arinto apresentaram uma idade média de 39,21 anos e os que provaram bolachas com incorporação de farinha de bagaço Touriga Nacional apresentaram uma idade média de 41,96 anos. Não foram observadas diferenças 
color, the highest score obtained was for the control cookie, and the lowest scores were obtained for the two incorporations of Touriga Nacional. Similar results were obtained in the case of flavor since the control cookie obtained the highest score and the Touriga Nacional with $15 \%$ of incorporation had the lowest score. The two varieties with $20 \%$ incorporation were described as the least favorite flavor, with a score of 3.83 points over a maximum of 5 . The cookie with 15\% incorporation of grape pomace from the Touriga Nacional variety was the most accepted texture compared to the rest of the samples analyzed. Finally, the highest score concerning the overall appreciation was for the control of sweet cookies, and secondly for the incorporation of $15 \%$ of estatisticamente significativas entre a idade e sexo dos provadores que avaliaram as duas castas. A Figura 2 mostra os resultados obtidos da avaliação sensorial de acordo com as diferentes castas e incorporações estudadas, na qual é possível observar diferenças estatisticamente significativas quanto à cor, sabor, gosto e textura. Relativamente à cor, a pontuação mais alta obtida foi para a bolacha controlo, e as pontuações mais baixas foram obtidas para as duas incorporações da casta Touriga Nacional. Resultados semelhantes foram obtidos no caso do sabor, uma vez que a bolacha controlo foi a que obteve uma pontuação mais alta e a Touriga Nacional com $15 \%$ de incorporação a que teve uma pontuação mais baixa. As duas castas com $20 \%$

Table 3 - Mean age according to gender and grape varieties

Tabela 3 - Média de idade de acordo com o género e castas utilizadas

\begin{tabular}{lcc}
\hline & Age, years / Idade, anos & p-value* \\
\hline Total population / População total $(\mathrm{n}=149)$ & $40.45(16.45)$ & - \\
Gender / Género & & \\
Men / Homem ( $=57)$ & $37.34(14.92)$ & 0.060 \\
Women / Mulher (n=92) & $42.38(17.13)$ & \\
Grape variety / Castas & & \\
$\quad$ Arinto ( $\mathrm{n}=83)$ & $39.21(17.19)$ & 0.696 \\
Touriga Nacional (n=66) & $41.96(15.50)$ & \\
\hline
\end{tabular}

Age is expressed as means (SD). *p-values for comparisons between groups were tested by Student's t-test /

Idade expressa em média (DP). *Valores P para comparações entre grupos foram testados mediante teste $t$ de Student.

Score / Pontuação ${ }^{\mathrm{a}}$

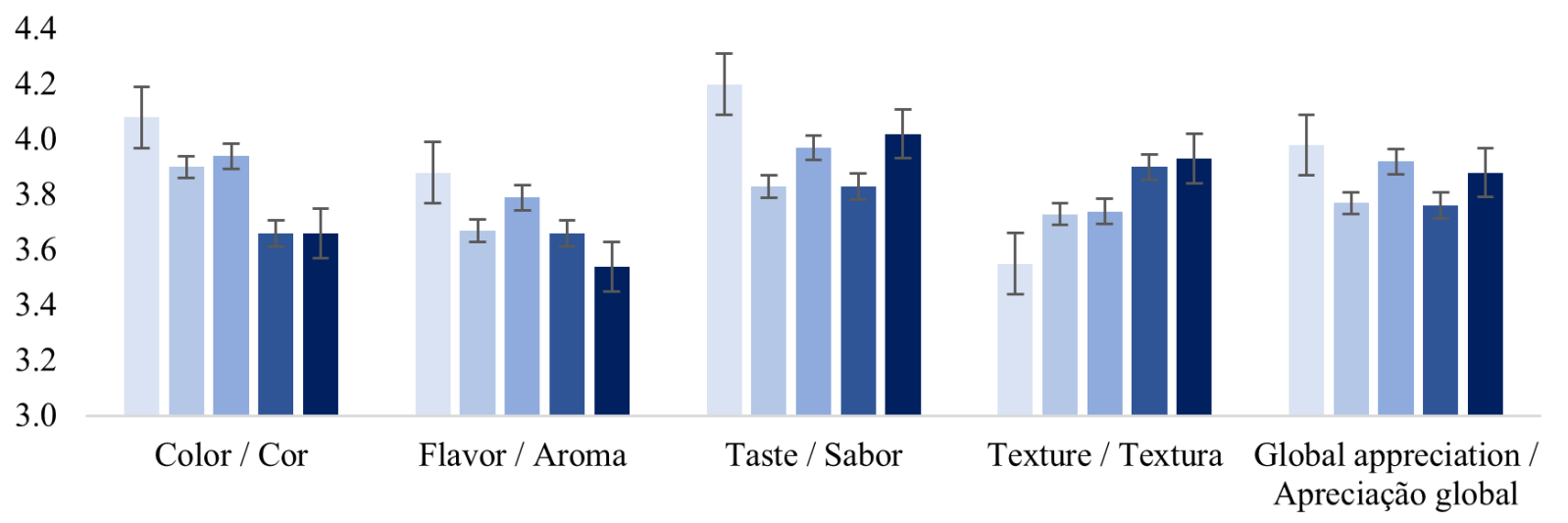

Control / Controlo $\square$ Arinto 20\% $\square$ Arinto 15\% $\square$ Touriga Nacional 20\% $\square$ Touriga Nacional 15\%

Figure 2 - Sensory evaluation according the different incorporation and grape varieties. Data expressed as means (SD). *p-value $<0.005$. a Score: Color, Aroma, Flavor, Texture, Global impression=1-Very unpleasant, 2-Unpleasant, 3-Indifferent, 4-Pleasant, 5-Very pleasant

Figura 2.- Análise sensorial de acordo as diferentes incorporações e castas. Dados expressos como média (DP). *Valores $\mathrm{P}<0.005$. a Pontuação: Cor, Aroma, Sabor, Textura, Impressão global=1- Muito desagradável, 2-Desagradável, 3-Indiferente, 4-Agradavél, 5-Muito agradável. 
Arinto grape pomace. The lowest score was obtained for the incorporation of $20 \%$ Touriga Nacional. These differences were not statistically significant, however, the preference for cookies with the incorporation of Arinto flour is a factor previously observed in the sensory evaluation study of Palma et al (19).

The intention of purchasing sweet cookies with 15 and $20 \%$ of grape pomace incorporation of Arinto and Touriga Nacional grape varieties can be observed in Figure 3. The highest percentage of individuals who reported that they would certainly buy was relative to the sweet cookies with 15 and $20 \%$ of Arinto grape pomace incorporation (32.1\% for each). The sweet cookies with the lowest purchase intention were the control sweet cookies since $6.4 \%$ of the total population reported that they had no intent to buy them de incorporação foram descritas como o sabor menos apreciado, tendo uma pontuação de 3,83 pontos sobre um máximo de 5 . A bolacha com $15 \%$ de incorporação de bagaço de uva da casta Touriga Nacional foi a textura mais aceite em comparação com o resto das amostras analisadas. Finalmente, a pontuação mais alta em relação à apreciação global foi para as bolachas doces controlo, e em segundo lugar para a incorporação de $15 \%$ de bagaço de uva de Arinto. A pontuação mais baixa foi obtida pela incorporação de $20 \%$ de Touriga Nacional. Estas diferenças não foram estatisticamente significativas, no entanto a preferência para bolachas com incorporação de farinha de Arinto é um fator já observado anteriormente, no estudo de avaliação sensorial de Palma et al (19).

A intenção de compra de bolachas doces com 15 e 20\% de incorporação de bagaço de uva das castas Arinto e Touriga Nacional pode ser observada na Figura 3. A maior percentagem de indivíduos que relataram que comprariam de certeza foi relativo às bolachas doces com incorporação de 15 e $20 \%$ de bagaço de uva Arinto (32,1\% para cada uma). As bolachas doces com a menor intenção de compra foram as bolachas doces controlo, uma vez que $6,4 \%$ da população total referiu que não os comprariam de certeza.

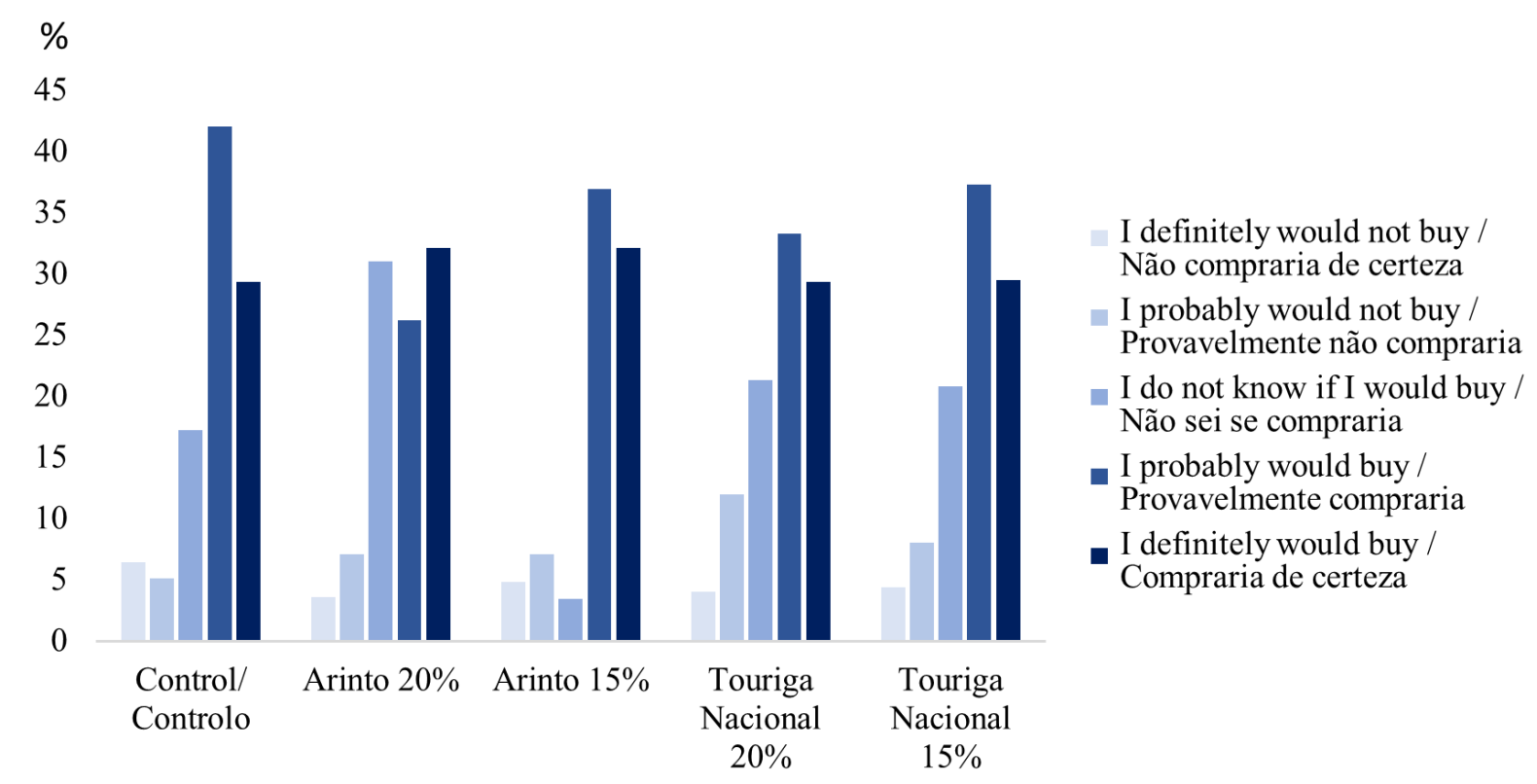

Figure 3 - Purchase intention for sweet cookies with incorporation $(15$ and $20 \%)$ of the Arinto variety $(n=84)$ and sweet cookies with incorporation $(15 \%$ and $20 \%)$ of the Touriga Nacional variety $(n=65)$. Data expressed as percentage $(\%)$.

Figura 3 - Intenção de compra para bolachas doces com incorporação $(15$ e $20 \%)$ da casta Arinto $(n=84)$ e para bolachas doces com incorporação $(15 \%$ e $20 \%)$ da casta Touriga Nacional $(n=65)$. Dados expressos como percentagem $(\%)$. 
Table 4 - Preference of sweet cookies selection

Tabela 4 - Preferência de escolha das bolachas doces

\begin{tabular}{|c|c|c|c|c|}
\hline & $\begin{array}{l}\text { Liked best / } \\
\text { Gostei mais }\end{array}$ & $\begin{array}{c}\text { More or less liked / } \\
\text { Gostei mais ou } \\
\text { menos }\end{array}$ & $\begin{array}{l}\text { Liked least / } \\
\text { Gostei menos }\end{array}$ & p-value* \\
\hline \multicolumn{5}{|l|}{ Type of flour / Tipo de farinha } \\
\hline Control/ Controlo $(n=149)$ & $40.9(61)$ & $18.1(27)$ & $40.9(61)$ & \multirow{3}{*}{$<0.001$} \\
\hline Arinto $(n=148)$ & $27.1(45)$ & $38.6(46)$ & $34.3(57)$ & \\
\hline Touriga Nacional (n=132) & $32.6(43)$ & $43.9(58)$ & $23.5(31)$ & \\
\hline p-value* & 0.033 & $<0.001$ & 0.008 & \\
\hline \multicolumn{5}{|l|}{ Grape pomace samples / } \\
\hline \multicolumn{5}{|l|}{ Amostras de farinha de bagaço } \\
\hline Arinto $15 \%(n=74)$ & $26.5(22)$ & $32.5(18)$ & $41.0(34)$ & \multirow{4}{*}{$<0.001$} \\
\hline Arinto $20 \%(n=74)$ & $27.7(23)$ & $44.6(28)$ & $27.7(23)$ & \\
\hline Touriga Nacional 15\% $(\mathrm{n}=66)$ & $34.8(23)$ & $37.9(25)$ & $27.3(18)$ & \\
\hline Touriga Nacional 20\% $(\mathrm{n}=66)$ & $30.3(20)$ & $50.0(33)$ & $19.7(13)$ & \\
\hline p-value* & 0.129 & $<0.001$ & 0.008 & \\
\hline \multicolumn{5}{|l|}{ \% Incorporation / \% Incorporação } \\
\hline $\begin{array}{l}\text { 15\% Incorporation / Incorporação } \\
(n=149)\end{array}$ & $30.2(45)$ & $34.9(52)$ & $34.9(52)$ & \multirow{2}{*}{$<0.001$} \\
\hline $\begin{array}{l}\text { 20\% Incorporation / Incorporação } \\
(\mathrm{n}=149)\end{array}$ & $28.9(43)$ & $47.0(70)$ & $24.2(36)$ & \\
\hline p-value* & 0.053 & $<0.001$ & 0.008 & \\
\hline
\end{tabular}

Data expressed as a percentage (n). *p-values for comparisons between groups were tested by Pearson $\chi 2$ / Dados expressos como percentagem (n). *Valores P para comparações entre grupos foram testados mediante Pearson $\chi^{2}$

Finally, Table 4 shows the preferences of choice among all the samples analyzed. Regarding the analysis according to the type of flour, statistically, significant differences were observed between these cookies and the classification of "liked more," "liked more or less," and "liked less." The most appreciated cookie was the control, followed by Touriga Nacional and finally, Arinto. These results are not in line with the opinion that the respondents expressed regarding individual parameters or overall appreciation. This apparent discrepancy is sometimes observed, as consumers can provide emotional type responses of "like" or "dislike" which do not always reflect the same pattern they express in the evaluation of various attributes on a hedonic scale of several points (20). Nevertheless, in this analysis of preference regarding the various incorporations and varieties, the most appreciated was Touriga Nacional with $15 \%$ grape pomace incorporation. However, these differences were not statistically significant. The highest percentage of individuals who appreciated less
Finalmente, a Tabela 4 mostra as preferências de escolha entre todas as amostras analisadas. Relativamente à análise de acordo com o tipo de farinha, foram observadas diferenças estatisticamente significativas entre estes biscoitos e a classificação de "gostei mais", "gostei mais ou menos", e "gostei menos". A bolacha mais apreciada foi a de controlo, seguida pela Touriga Nacional e por último a Arinto, resultados que não estão em linha com a opinião que os inquiridos expressaram relativamente aos parâmetros individuais ou apreciação global, este fato é algumas vezes observado, na medida em que os consumidores face a respostas do tipo emocional "gosto" ou "não gosto", nem sempre refletem o mesmo comportamento que expressam frente à avaliação de vários atributos numa escala hedônica de vários pontos (20). Ainda nesta análise de preferência relativa às várias incorporações e castas, a mais apreciada foi a Touriga Nacional com $15 \%$ de incorporação de bagaço de uva. Contudo, estas diferenças não foram estatisticamente significativas. 
was relative to the sweet cookie with $15 \%$ incorporation of Arinto grape pomace. Finally, when the data were analyzed according to the incorporation percentage, the most appreciated sweet cookie was the one with $15 \%$ grape pomace incorporation, however, the differences were not statistically significant between the varieties. The highest percentage of individuals who did not appreciate the cookies analyzed also referred to the incorporation of $15 \%$ of grape pomace, thus, these results were inconclusive. It should be noted that the choice of $15 \%$ and $20 \%$ of grape pomace flour incorporation is related to the results obtained in a previous study conducted by Palma et al., in which the participants showed a clear preference for samples that contained the highest percentage of incorporation (15\%). Also, previous studies with other matrices used percentages of incorporation of $20 \%(21-23)$, which is why we consider it important to evaluate the acceptability of the participants for higher incorporation than we had previously studied.

The main limitation of the study was the pandemic context and the recommendations and norms of the General Directorate of Health (DGS), which made it impossible to gather a group of trained tasters and used the methodology indicated for these types of tests. Other limitations were the form in which we accessed each participant's opinion, as the questionnaire created through the Google Forms platform appeared not suitable for an overaged population. Another limitation was the exclusion and inclusion criteria; in the current context, the only criteria used were the availability and willingness to participate. The main strength was the possibility of assessing, for the first time, the acceptability of cookies with a $20 \%$ incorporation of grape flour. The maximum we had previously tested was $15 \%$ incorporation.

\section{Conclusion}

The results obtained although they show a preference for the control cookie, the differences are not statistically significant. It is not possible to conclude from these results which is the most appreciated incorporation by consumers. In the assessment with several attributes and the overall assessment, the respondents refer a preference for the cookie with $15 \%$ incorporation of flour from Arinto, without statistically significant differences. However, faced with the option of choosing between "liked a lot," "liked more or less" and "did not like," the cookie with the highest score, with statistically significant differences, is the cookie
A percentagem mais elevada de indivíduos que menos apreciaram, foi relativa à bolacha doce com incorporação de $15 \%$ de bagaço de uva de Arinto. Finalmente, quando se analisaram os dados em função da percentagem de incorporação, a bolacha doce mais bem aceite foi a que continha $15 \%$ de incorporação de bagaço de uva, no entanto, as diferenças não foram estatisticamente significativas entre as castas. A maior percentagem de indivíduos que não apreciaram as bolachas analisadas, referiu-se também à incorporação de $15 \%$ de bagaço de uva, sendo estes resultados pouco conclusivos. De salientar que a escolha de $15 \%$ e $20 \%$ de incorporação de farinha de bagaço de uva, está relacionada com os resultados obtidos num estudo anterior realizados por Palma et al, na qual os participantes mostraram uma clara preferência para as amostras que continham a maior percentagem de incorporação (15\%), para além disso estudos anteriores (21-23) com outras matrizes usaram percentagens de incorporação de $20 \%$, razão pela qual consideramos importante avaliar a aceitabilidades dos participantes para uma incorporação superior à que anteriormente tínhamos estudado.

A principal limitação do estudo foi o contexto pandémico e as recomendações e normas da Direção Geral da Saúde (DGS), por causa delas foi impossível reunir um grupo de provadores formados e utilizar a metodologia indicada para estes tipos de testes. Outras limitações foram a forma em que acedemos ao parecer do participante, o questionário criado através da plataforma Google Forms parece não ser adequado a uma população com excesso de idade. Outra limitação é o critério de exclusão e inclusão, no contexto atual, o único critério utilizado foi a disponibilidade e a vontade de participar. O principal ponto forte foi a possibilidade de avaliar a aceitabilidade dos cookies com uma incorporação de $20 \%$ de farinha de uva, um valor nunca antes avaliado, uma vez que o máximo que tínhamos testado até agora tinha sido uma incorporação de $15 \%$.

\section{Conclusões}

Os resultados obtidos embora mostrem uma preferência para a bolacha controlo não existem diferenças estatisticamente significativas entre eles. Face aos resultados não é possível concluir qual a incorporação mais apreciada pelos consumidores, já que, na apreciação com vários atributos e na apreciação global os inquiridos referem uma preferência, sem diferenças significativas, para a bolacha com $15 \%$ de incorporação de farinha de Arinto, mas face à opção de escolha entre "gostei 
with 15\% incorporation of flour from Touriga Nacional. The results showed a preference of consumers for the incorporation of $15 \%$ for both Arinto and Touriga Nacional flours, however, given the preliminary character of this study, we consider that other studies should be conducted with trained tasters in which increased incorporation of grape pomace flour is evaluated in both sweet and salty matrices.

\section{Authors Contributions Statement}

M.N, M.L.P, P.P - conceptualization and study design; M.N, M.L.P, P.P - experimental implementation; C.F.P. - data analysis; M.N, M.L.P, P.P, C.F.P. - drafting, editing and reviewing; C.F.P. - figures and graphics; M.N, M.L.P, P.P, C.F.P. - supervision and final writing.

\section{Funding}

This research was funded by Fundação para a Ciência e a Tecnologia (FCT, Portugal), through projects UIDP/04567/2020 and UIDB/04567/2020. P.P. Gratefully acknowledges the support of the CERENA strategic project FCT-UID/ECI/04028/2019.

C.F-P. is funded by Foundation for Fundação para a Ciência e a Tecnologia (FCT) Scientific Employment Stimulus contract with the reference number CEEC/ CBIOS/NUT/2018.

\section{Acknowledgments}

The authors acknowledge all the participants.

\section{Conflict of Interests}

The authors declare that no financial or personal relationship could present a potential conflict of interest. muito", Gostei mais ou menos" e "não gostei" a bolacha que tem maior score, com diferenças estatisticamente significativas, é a bolacha com $15 \%$ de incorporação de farinha de Touriga Nacional. Os resultados mostraram uma preferência dos consumidores pela incorporação de $15 \%$ tanto para a farinha de Arinto como para a de Touriga Nacional, contudo dado o caráter preliminar deste estudo consideramos que devem ser realizados outros estudos com provadores treinados em que o aumento da incorporação seja avaliado, tanto em matrizes doces como salgadas.

\section{Declaração sobre as contribuições do autor}

M.N, M.L.P, P.P - conceção e desenho do estudo; M.N, M.L.P, P.P. - implementação experimental; C.F.P. - análise de dados; M.N, M.L.P, P.P, C.F.P - redação, edição e revisão; C.F.P - figuras e gráficos; M.N, M.L.P, P.P, C.F.P - supervisão e redação final.

\section{Financiamento}

Este trabalho é financiado por fundos nacionais através da FCT - Fundação para a Ciência e Tecnologia, I.P., ao abrigo dos projetos UIDB/04567/2020 e UIDP/04567/2020.

Cíntia Ferreira Pêgo é financiada pela Fundação para a Ciência e Tecnologia (FCT) mediante o Contrato de Estímulo ao Emprego Científico com o número de referência CEEC/CBIOS/NUT/2018.

\section{Agradecimentos}

Os autores agradecem a todos os participantes.

\section{Conflito de Interesses}

Os autores declaram que não existe uma relação financeira ou pessoal que possa ser entendida como representando um potencial conflito de interesses. 


\section{References / Referências}

1 Organização das Nações Unidas (2015). Objetivos de desenvolvimento sustentável e o BCSD Portugal. Retrieved from https://unric. org/pt/objetivos-de-desenvolvimento-sustentavel/

2. Gómez-Brandón, M., Lores, M., Insam, H., \& Domínguez, J. (2019). Strategies for recycling and valorization of grape marc. Critical Reviews in Biotechnology, 39(4), 437-50. https://www.tandfonline.com/doi/abs/10.1080/07388551.2018.1555514

3. Costa, M., Torres, A., Fernandes, A., Freitas, J., Teodósio, J., Pintado, M., \& Leandro, E. (2007). a avaliação da qualidade do composto de bagaço de uva como fertilizante orgânico. Actas Portuguesas de Horticultura, 85-92.

4. Fontana, A. R., Antoniolli, A., \& Bottini, R. (2013). Grape pomace as a sustainable source of bioactive compounds: Extraction, characterization, and biotechnological applications of phenolics. Journal of agricultural and food chemistry, 61(38), 8987-9003.

5. Oliveira, V.P.F. (2016). Valorização de subprodutos da vinha e do vinho - composição fenólica e atividade antioxidante [tese de Mestrado, Universidade Lusófona] de Humanidades e Tecnologias. http://hdl.handle.net/10437/7213

6. Zacharof, M.P. (2017). Grape winery waste as feedstock for bioconversions: Applying the biorefinery concept. Waste Biomass Valor, 8, 1011-25. https://doi.org/10.1007/s12649-016-9674-2

7. Soto, M.L., Falqué, E., \& Domínguez, H. (2015). Relevance of natural phenolics from grape and derivative products in the formulation of cosmetics. Cosmetics, 2, 259-76. https://doi.org/10.3390/cosmetics2030259

8. Leal, C., Gouvinhas, I., Santos, R.A., Rosa, E., Silva, A.M., Saavedra, M.J., \& Barros, A.I.R.N.A. (2020). Potential application of grape (Vitis vinifera L.) stem extracts in the cosmetic and pharmaceutical industries: valorization of a by-product. Industrial Crops and Products, 154:112675. https://doi.org/10.1016/j.indcrop.2020.112675

9. García-Lomillo, J., \& González-SanJosé, M. L. (2017). Applications of wine pomace in the food industry: Approaches and functions. Comprehensive reviews in food science and food safety, 16(1), 3-22. https://doi.org/10.1111/1541-4337.12238.

10. Strapasson, G. C. (2016). Caracterização e utilização do resíduo de produção de vinho no desenvolvimento de alimentos com propriedade funcional. [tese de doutoramento, Universidade Federal do Paraná] Universidade Federal do Paraná. https://hdl.handle.net/1884/42386

11. Yu, J. \& Ahmedna, M. (2013). Functional components of grape pomace: Their composition, biological properties and potential applications. International Journal of Food Science and Technology, 48, 221-37. https://doi.org/10.1111/j.1365-2621.2012.03197.x

12. Instituto Nacional de Estatística. (2021). Boletim Mensal da Agricultura e Pescas : janeiro de 2021. Retrieved March 5, 2021, from https://www.ine.pt/xurl/pub/71883762

13. Hogervorst J. C., Miljić U., \& Puškaš, V. (2017). Extraction of bioactive compounds from grape processing by-products. In Charis M. Galanakis (Eds.), Grape Processing By-Products (pp105-135). Handbook of Academic Press. ISBN 9780128098707 https://doi. org/10.1016/B978-0-12-809870-7.00005-3

14. Nicolai, M., Pereira, P., Rijo, P., Amaral, O., Amaral, A.,\& Palma, L. (2018). Vitis vinifera L. pomace: Chemical and nutritional characterization. Biomedical and Biopharmaceutical Research Journal, 15(2), 156-66. http://www.alies.pt/BBR\%20Editions/Vol-15-2-2018/ art2.pdf

15. Antoniolli, A., Fontana, A. R., Piccoli, P., \& Bottini, R. (2015). Characterization of polyphenols and evaluation of antioxidant capacity in grape pomace of the cv. Malbec. Food Chemistry, 178, 172-8. https://doi.org/10.1016/j.foodchem.2015.01.082

16. Fontana, A., Antoniolli, A., D’Amario Fernández, M. A., \& Bottini, R. (2017). Phenolics profiling of pomace extracts from different grape varieties cultivated in Argentina. RSC Advances, 7(47), 29446-57. https://doi.org/10.1039/C7RA04681B

17. Abreu J, Quintino I, Pascoal G, Postingher B, Cadena R, \& Teodoro A. (2019). Antioxidant capacity, phenolic compound content and sensory properties of cookies produced from organic grape peel (Vitis labrusca) flour. Int J Food Sci Technol., 54(4), 1215-24. https:// ifst.onlinelibrary.wiley.com/doi/abs/10.1111/ijfs.14100

18. Mildner-Szkudlarz, S., Bajerska, J., Zawirska-Wojtasiak, R., \& Górecka, D. (2013). White grape pomace as a source of dietary fibre and polyphenols and its effect on physical and nutraceutical characteristics of wheat biscuits. Journal of the Science of Food and Agriculture, 93(2), 389-95. https://doi.org/10.1002/jsfa.5774

19. Palma, M.L., Nunes, M.C., Gameiro, R., Rodrigues, M., Gothe, S., Tavares, N., Pego, C., Nicolai, M., \& Pereira, P. (2020) Preliminary sensory evaluation of salty crackers with grape pomace flour. Biomedical and Biopharmaceutical Research Journal, 17(1), 33-43. http://alies.pt/BBR\%20Editions/Vol-17-1-2020/bbr.17.1.222.pdf

20. Civille, G. V., \& Oftedal, K. N. (2012). Sensory evaluation techniques - make "good for you" taste "good". Physiology \& Behavior, 107(4), 598-605. https://doi.org/10.1016/j.physbeh.2012.04.015

21. Kuchtová, V., Kohajdová, Z., Karovičová, J., \& Lauková, M. (2018). Physical, textural and sensory properties of cookies incorporated with grape skin and seed preparations. Polish Journal of Food and Nutrition Sciences, 68(4), 309-17. https://doi.org/10.2478/ pjfns-2018-0004

22. Kuchtová, V., Karovičová, J., Kohajdová, Z., Minarovičová, L., \& Kimličková, V. (2016). Effects of white grape preparation on sensory quality of cookies. Acta Chimica Slovaca, 9(2), 84-8. https://doi.org/10.1515/acs-2016-0014

23. Civille, G.V., \& Carr, B.T. (2015). Sensory evaluation techniques. (5th ed.). CRC Press, https://doi.org/10.1201/b19493 